\title{
Quality Analysis of Ash from Lignite Coal and its Utilization at Thar Power Plant
}

\author{
Deepak Kumar \\ Shaheed Zulfikar Ali Bhutto Institute of Science and Technology, Hyderabad \\ E-mail: deepakdrathi@gmail.com
}

Bharat Lal

Department of Electronic Engineering, Mehran UET Jamshoro

E-mail: bharat.lal@faculty.muet.edu.pk

\section{Mukesh Kumar}

Department of Chemical Engineering, Mehran UET Jamshoro

E-mail: karmanimukesh44@gmail.com

\author{
Shanker Lal Meghwar \\ Department of Civil Engineering, Mehran UET Jamshoro \\ E-mail: shanker.lal@faculty.muet.edu.pk
}

Received: 02 April 2021; Accepted: 20 May 2021; Published: 08 June 2021

\begin{abstract}
Billion of tonnes lignite coal is deposited under the surface of Tharparkar zone had been started utilizing in its own mine mouth power plant. Tharparkar is rich in coal resource and have the potential to energize the Pakistan for at least 200 year with the deposited coal fuel of 175 Billion of tonnes. Thar coal further divided into 13 blocks; Block II (have $1 \%$ of 175 Billion of tonnes of coal has the capability of produce $5000 \mathrm{MW}$ for 50 years) had just set its 2 units which is capable for 2x330 MW with coal consumption of 560 tons/hour. With the time, the increase in thermal power plant will results in increasing problems with the disposal of solid residues from combustion and off gas cleaning (Bottom ash and Fly ash). The properties of as fired coal is analyzed i.e, volatile matter, sulfur and nitrogen contents and solid residues from combustion and off gas cleaning (Bottom \& Fly Ash) and it's found that as fired coal consists of $12 \%$ ash which is $5 \%$ greater than ash of design coal that is $7 \%$ and ranges from $4-12 \%$. Large amount of ash produced by as fired coal reaches the almost upper range of ash in designed coal and yet it's not utilized or recycled, according to analysis it can be utilized in various forms i.e. CLC block, cements, road construction and agriculture, if it is not recycled in future then it will create bad impact to the environment like environment pollution, health concern to the human and wildlife and contaminant the under-ground water.
\end{abstract}

Index Terms: Ash, Coal, Thermal Power Plant, Quality Analysis.

\section{Introduction}

Coal based thermal power plants are still popular and cheap source of energy in many developing countries. Thermal power plants have been major source of power generation in Pakistan, for many years [1]. The energy crisis is increasing day by day and Pakistan government has planned to increase the power generation capacity up to $22000 \mathrm{MW}$ by 2035 through coal based thermal power plants [2]. The total coal reserves in Pakistan are estimated at 185 Billion tonnes, out of which 175 Billion tonnes are found in district Tharparkar under an area of 10,000 sq. km [2]. The coal is natural and cheap energy source and under developing countries moving towards, production of energy from coal [3]. Thar coal reserves have the capacity of producing energy of $100,000 \mathrm{MW}$ by consumption of 536 Million tons of coal per year which is approximated to produce same amount of energy for more than 200 years [4]. The total coal reserves are greater than the summation of total oil reserves of Saudi Arabia and Iran together [5]. Not only coal thermal plants produce energy but at the same time they produce solid waste byproduct in bulk amount i.e. slag, bottom ash and fly ash. Disposal of solid waste from coal-fired power plants is becoming a serious challenge to the environmentalists [6]. In addition, it is found that emissions of gasses SOx, NOx, SPM, RSPM and other gases effects the surrounding environment badly [7-8]. The major drawback of coal based thermal power plants is disposal of waste product and emission of greenhouse gases [9]. However, nowadays the byproduct of coal is being recycled and used in manufacturing of bricks and partial replacement of cement in concrete [10]. 
The coal found in Tharparkar district is lignite type and as per design coal it consist of approximate 7-10\% of ash. Thar coal reservoirs are divided in to 13 blocks. Currently, Block II (owned by Sindh Engro Coal Mining Company) is in operational. This block is capable of producing $5000 \mathrm{MW}$ of electricity over the span of next 50 years which will consume 1.75 Billion tons of coal (i.e. $1 \%$ of total Thar coal reserves). The first thermal power plant has already started in July, 2019 , and currently it is generating $660 \mathrm{MW}$ of electricity with coal consumption of 13440 tons/day with full capacity and produces ash about 1344 tons/day. At the moment, this ash is being dumped which will cause serious problems, like respiratory diseases in those who are living nearby the coal plant in long term. The fly ash has cementitious properties and it can be used along with cement in concrete manufacturing. To use fly ash as secondary cementitious in concrete, it needs to be chemically analyzed to know the composition of different compounds present in ash. Thus, objective of this study is to analyze the quality of different types of Thar Coal Ash and discuss gaps and possibilities to dispose and recycle the ash at local level.

\section{Quality Analysis of Ash and Coal}

\section{A. Analysis of Coal}

In this research different samples of as fired coal was taken on daily basis for one week and tests was performed in Chemical Laboratory of EPTL (Engro Powergen Thar Pvt. Ltd.). The LC-233 ESPEC equipment was used for total moisture. Quick Intelligence Sulfur determination device was used for finding the total sulfur, and Automatic Bomb Calorimeter was used for calorific value of coal. The coal Proximate Analysis is shown in Table 1. It is clear from chemical composition of coal that average ash includes in as fired coal is $10.41 \%$.

Table 1. As fired coal- lab report analysis (proximate composition)

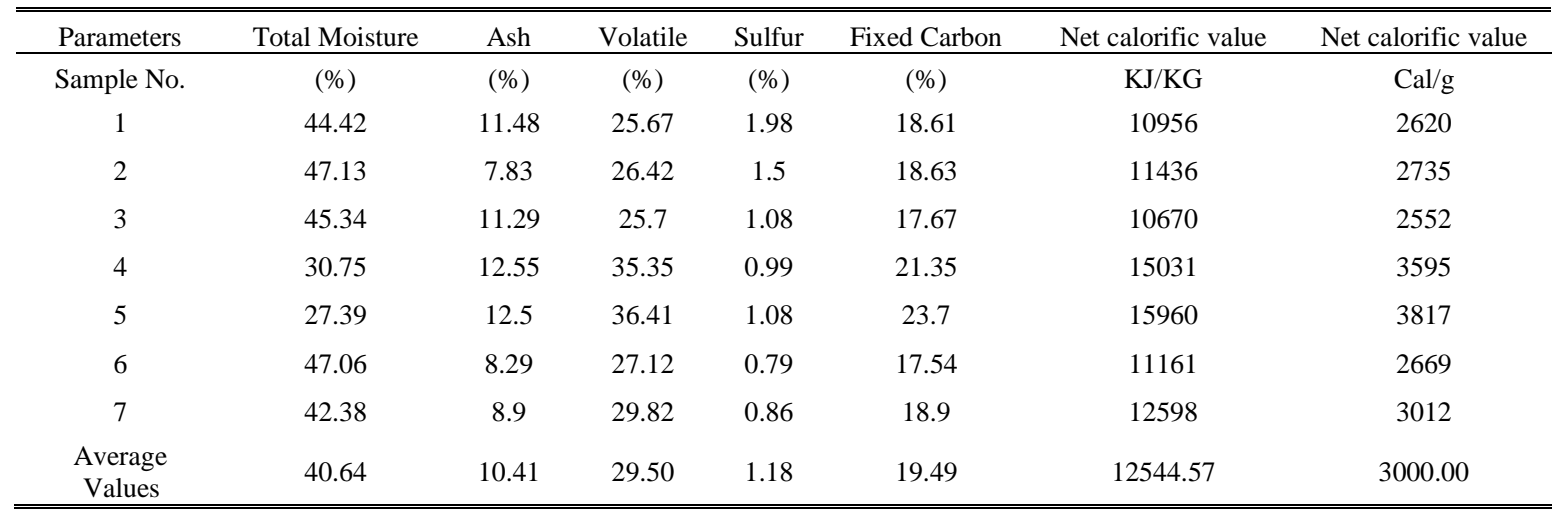

B. Analysis of Ash

After the combustion of coal in boiler's furnace, two by products are generated first is Bottom Ash and second is Flue Gases. The bottom Ash or Slag is discharge through the bottom of furnace and remaining flue gases are passed through the heat recovery zone (Back Pass of Boiler). It flows through the Electrostatic Precipitator ESP (ESP is equipment used to clean the off-gas through the electro static charges and extract it into the fly ash and clean gas). The Fly Ash is conveyed through pneumatic lines and collected into the ash silos. In terms of economic the total ash is approximate $10 \%$ of its coal value.

The ash sample was collected from different taps and test was performed at EPTL Chemical Lab on SPECTRO XRD equipment.

\section{Bottom Ash}

The Bottom Ash or Slag discharges from the bottom of Boiler's Furnace. It is composed of coarse and granular, incombustible by-products. To remove the bottom ash, it is kept in molten state and tapped off in liquid passing through the slag discharge ash cooler (which are also used for heat recovery medium) and put off through conveyors to Silo. Bottom ash from Lignite Coal type contains approximate $35 \%$ of Silicon di Oxide, $18 \%$ of Calcium Oxide and $15 \mathrm{~kJ} / \mathrm{Kg}$ of Ferric Oxide. The oxides analysis and particles size analysis results are given in Table 2 and 3. 
Table 2. Bottom ash XRF analysis

\begin{tabular}{cccc}
\hline \hline Oxides in $\mathrm{Ash}$ & Units & Sample 1 & Sample 2 \\
\hline Sodium oxide Na2O & $(\%)$ & 3.93 & 3.94 \\
Magnesium oxide $\mathrm{MgO}$ & $(\%)$ & $<0$ & $<0$ \\
Aluminum oxide $\mathrm{Al} 2 \mathrm{O} 3$ & $(\%)$ & 17.04 & 17.91 \\
Silicon oxide $\mathrm{SiO} 2$ & $(\%)$ & 35.49 & 35.2 \\
Phosphorus oxide P2O5 & $(\%)$ & 0.12 & 0.11 \\
Sulfur oxide SO3 & $(\%)$ & 8.28 & 7.49 \\
Potassium oxide K2O & $(\%)$ & 0.16 & 0.16 \\
Calcium oxide CaO & $(\%)$ & 18.59 & 16.41 \\
Titanium oxide TiO2 & $(\%)$ & 2.01 & 2.1 \\
Iron oxide Fe2O3 & $\mathrm{KJ} / \mathrm{KG}$ & 15.82 & 16.82 \\
Concentration Summation & & 101.45 & 100.15 \\
\hline \hline
\end{tabular}

Table 3. Bottom Ash particles size distribution

\begin{tabular}{cccc}
\hline \hline Particle Size $(\mathrm{mm})$ & Std. Unit & Sample 1 & Sample 2 \\
\hline$>20$ & $(\%)$ & 0 & 0 \\
$20-10.0$ & $(\%)$ & 1.7 & 0 \\
$10.0-5.6$ & $(\%)$ & 1.65 & 0.59 \\
$5.6-3.35$ & $(\%)$ & 1.43 & 0.91 \\
$3.35-1.0$ & $(\%)$ & 5.51 & 4.58 \\
$1.0-0.5$ & $(\%)$ & 10.19 & 9.87 \\
$0.5-0.25$ & $(\%)$ & 24.97 & 27.88 \\
$0.25-0.106$ & $(\%)$ & $/$ & $/$ \\
$0.106-0.075$ & $(\%)$ & 52.62 & 54.23 \\
$<0.075$ & $(\%)$ & 1.84 & 1.86 \\
Dmax & $\mathrm{mm}$ & 16 & 9 \\
\hline \hline
\end{tabular}

\section{Fly Ash}

Fly ash is recovered from flue gas through the off-gas cleaning method using ESP after passing through the heat recovery zone. The fine particles are ionized and extracted by field on plate. The collected particles are continuously hammered and disposed through the vessels. The vessel convey it to the Ash Silos through Pneumatic medium. Fly ash consists of silt-sized particles which are generally spherical, typically ranging in size between 10 and 100 micron. It consists primarily of oxides of Silicon, Aluminum, Iron, Sulfur and Calcium as given in Table 4. The fly ash at Thar power plant contains around $16 \%$ of Calcium oxide $(\mathrm{CaO})$, thus it is classified as "Class C" according to ASTM C618-19.

Table 4. Fly ash XRF analysis

\begin{tabular}{cccc}
\hline \hline Oxides in $\mathrm{Ash}$ & Units & Sample 1 & Sample 2 \\
\hline Sodium oxide $\mathrm{Na2O}$ & $(\%)$ & 1.67 & 1.63 \\
Magnesium oxide $\mathrm{MgO}$ & $(\%)$ & 3.57 & 3.47 \\
Aluminum oxide $\mathrm{Al2O} 3$ & $(\%)$ & 13.25 & 14.98 \\
Silicon oxide $\mathrm{SiO} 2$ & $(\%)$ & 37.03 & 37.18 \\
Phosphorus oxide $\mathrm{P} 2 \mathrm{O} 5$ & $(\%)$ & 0.08 & 0.08 \\
Sulfur oxide $\mathrm{SO} 3$ & $(\%)$ & 10.57 & 9.45 \\
Potassium oxide $\mathrm{K} 2 \mathrm{O}$ & $(\%)$ & 0.1 & 0.11 \\
Calcium oxide $\mathrm{CaO}$ & $(\%)$ & 16.39 & 14.92 \\
Titanium oxide $\mathrm{TiO} 2$ & $(\%)$ & 1.93 & 1.99 \\
Iron oxide $\mathrm{Fe} 2 \mathrm{O} 3$ & $\mathrm{KJ} / \mathrm{KG}$ & 16.3 & 17.39 \\
Concentration Summation & & 100.91 & 101.21 \\
\hline \hline
\end{tabular}

\section{Ash Disposal}

Generally, disposal of ash is one of the major problems for coal-based thermal power plants. When lignite coal type is burnt it produces approximately $69.3 \%$ of fly ash and $30.7 \%$ of bottom ash. Currently, the fly ash produced at Thar Coal Power plant is about 24502.6 tones/month, and bottom ash is about 10851.6 tones/month. The ash occupies around 120,000 sq. meter of land with four meter in-depth of ash disposal pond. However, it is expected that the ash disposal is going to soar at around 212,128.8 tons per year. Ash disposal on daily basis for fifteen days (i.e., 1st Sept. 2019 to 15th Sept. 2019) is shown in Table 5. 
Table 5. Fortnightly ash disposal report

\begin{tabular}{ccc}
\hline \hline Day & $\begin{array}{c}\text { Fly Ash Disposed } \\
\text { (In tons ) }\end{array}$ & $\begin{array}{c}\text { Bottom Ash Disposed } \\
\text { (in tons) }\end{array}$ \\
\hline 1 & 826.44 & 499.88 \\
2 & 1005.68 & 480.58 \\
3 & 943.62 & 460.88 \\
4 & 956.66 & 407.98 \\
5 & 958.8 & 357.84 \\
6 & 924.88 & 288.1 \\
7 & 876.72 & 429.96 \\
8 & 906.18 & 245.1 \\
9 & 1039.06 & 409.34 \\
10 & 1137.12 & 362.48 \\
11 & 1048.26 & 313.14 \\
12 & 1058.94 & 259.16 \\
13 & 1112.34 & 318.76 \\
14 & 991.96 & 502.26 \\
15 & 1027.62 & 447.78 \\
Total Ash & 14814.28 & 5783.24
\end{tabular}

\section{Coal Consumption and Energy Generation}

Table 6 shows fifteen days coal consumption in two units (i.e., 330MW of each). The average coal consumption of Unit 1 is 82541.126 tons and 80761.27 tons for Unit 2. While Figure 1 shows trend of coal consumption in fifteen days.

Table 6. Coal consumption table for fifteen days

\begin{tabular}{cccc}
\hline \hline Day & $\begin{array}{c}\text { Unit 1 coal } \\
\text { consumption (in } \\
\text { tons) }\end{array}$ & $\begin{array}{c}\text { Unit 2 coal } \\
\text { consumption (in tons) }\end{array}$ & $\begin{array}{c}\text { Total coal consumption in } \\
\text { tons }\end{array}$ \\
\hline Day 1 & 5786.86 & 6163.55 & 11950.41 \\
Day 2 & 5199.73 & 6249.28 & 11449.01 \\
Day 3 & 5797.25 & 5667.88 & 11465.13 \\
Day 4 & 5815.4 & 4669.7 & 10485.1 \\
Day 5 & 4729.605 & 4156.4 & 8886.005 \\
Day 6 & 5300.695 & 4528.62 & 9829.315 \\
Day 7 & 5551.8 & 4292.22 & 9844.02 \\
Day 8 & 5830.1 & 4997.7 & 10827.8 \\
Day 9 & 5603.61 & 5138.8 & 10742.41 \\
Day 10 & 5430.9 & 5543.1 & 10974 \\
Day 11 & 5536.9 & 5495.55 & 11032.45 \\
Day 12 & 5170.5 & 5500 & 10670.5 \\
Day 13 & 5378.08 & 5833.25 & 11211.33 \\
Day 14 & 5580.318 & 6108.17 & 11688.488 \\
Day 15 & 5829.378 & 6417.05 & 12246.428 \\
Total Consumption per & 82541.126 & 80761.27 & 163302.396 \\
15 days & & &
\end{tabular}




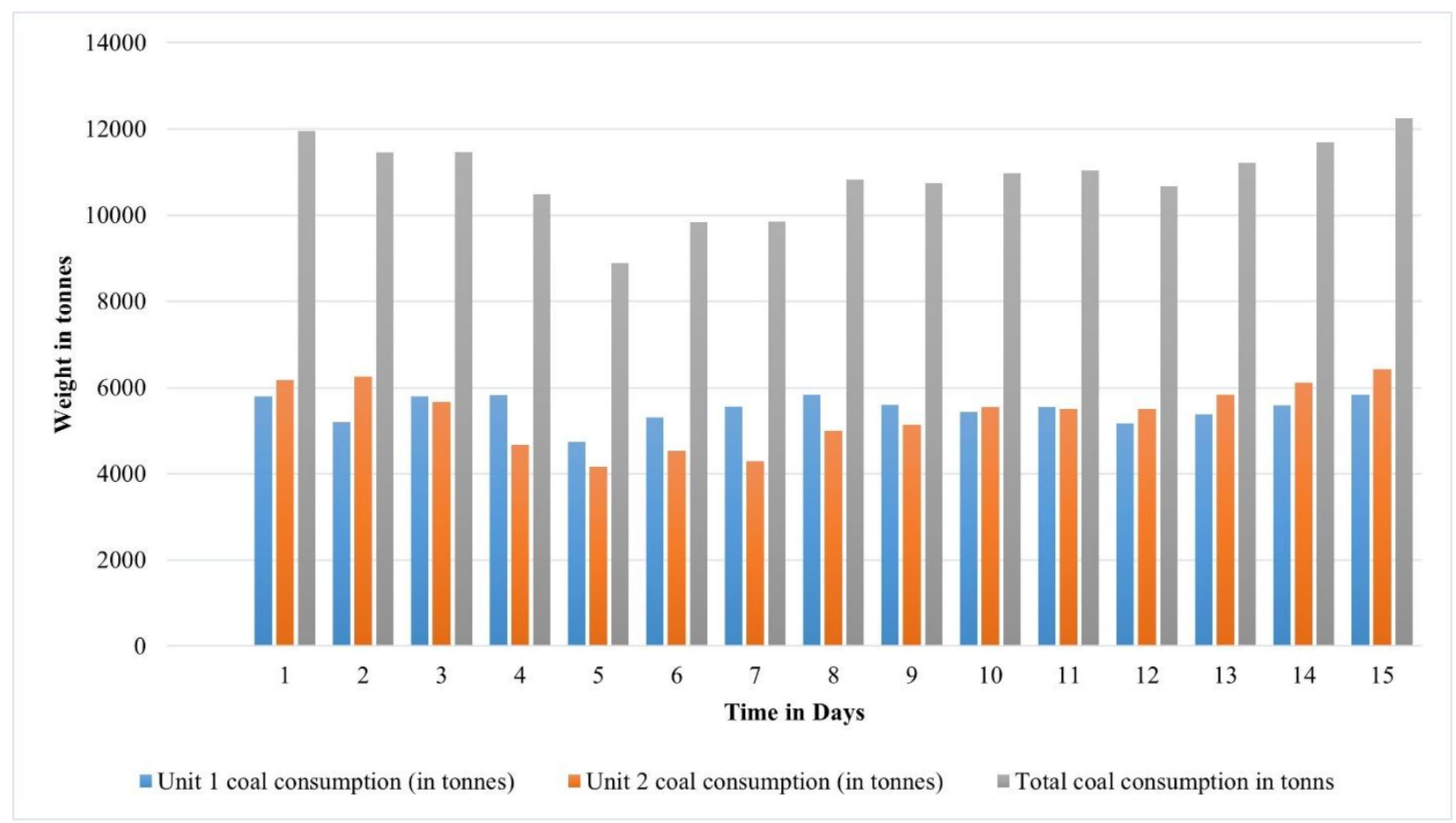

Fig.1. Total coal consumption chart for fifteen days

Table 7 and Figure 2 shows the net Ash (fly ash and bottom ash) disposal for fifteen days and corresponding total coal consumption for both the units. According to chemical analysis as given in Table 1 the average ash contents in coal is $10.41 \%$ but from 15 days report on coal consumption and ash disposal, the ash production is about $12.6 \%$ which is slightly higher.

Table 7. Coal consumption and ash production in tons for fifteen days

\begin{tabular}{cccc}
\hline \hline S.No & Day & Coal Consumption & Net Ash Disposal \\
\hline 1 & Day 1 & 11950.41 & 1326.32 \\
2 & Day 2 & 11449.01 & 1486.26 \\
3 & Day 3 & 11465.13 & 1404.5 \\
4 & Day 4 & 10485.1 & 1364.64 \\
5 & Day 5 & 8886.005 & 1316.64 \\
6 & Day 6 & 9829.315 & 1212.98 \\
7 & Day 7 & 9844.02 & 1306.68 \\
8 & Day 8 & 10827.8 & 1151.28 \\
9 & Day 9 & 10742.41 & 1448.4 \\
10 & Day 10 & 10974 & 1499.6 \\
11 & Day 11 & 11032.45 & 1361.4 \\
12 & Day 12 & 10670.5 & 1318.1 \\
13 & Day 13 & 11211.33 & 1431.1 \\
14 & Day 14 & 11688.488 & 1494.22 \\
15 & Day 15 & 12246.428 & 1475.4 \\
Total Consumption per 15 days & 163302.396 & 20597.52 \\
& & & \\
\hline \hline
\end{tabular}




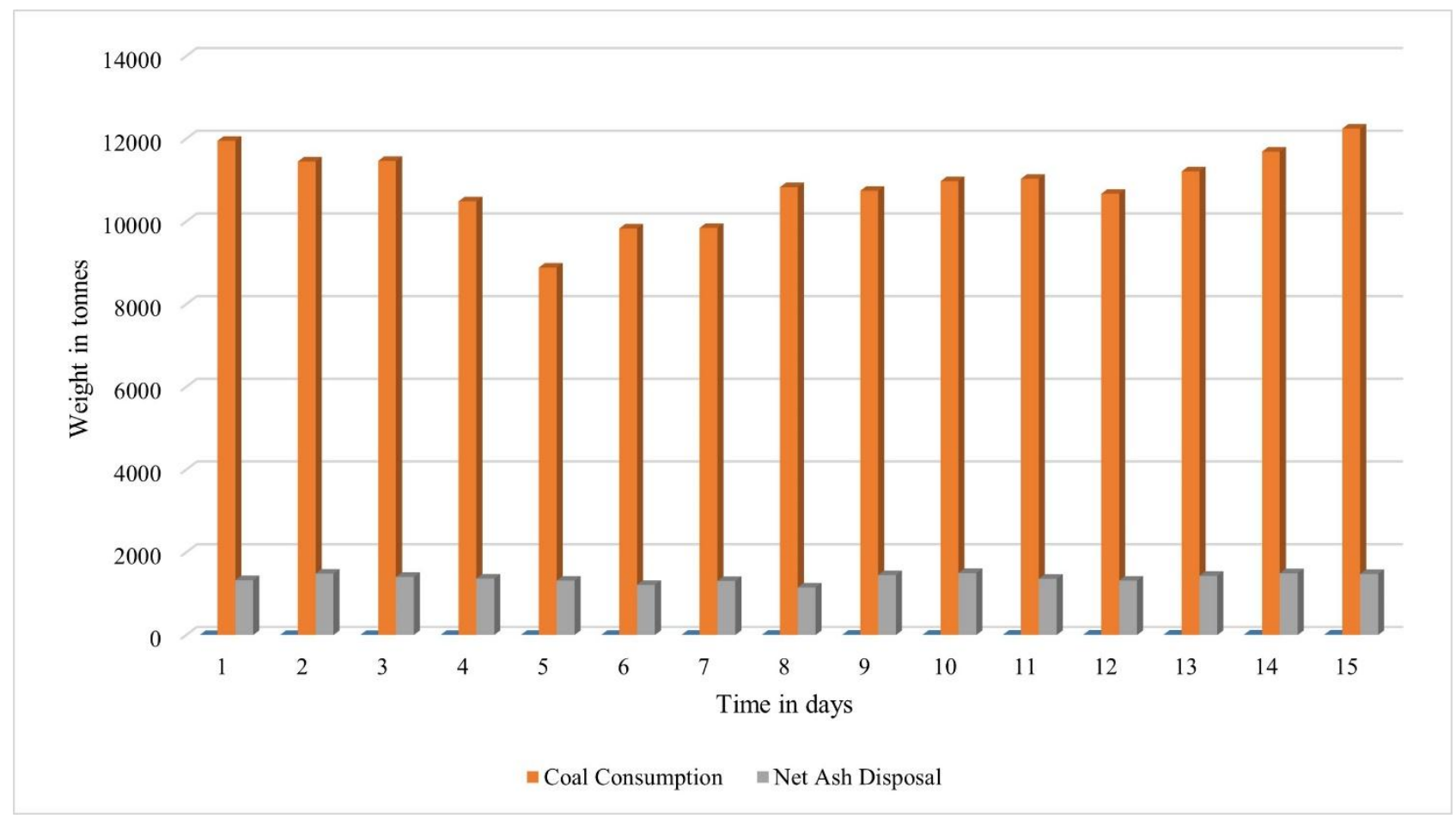

Fig.2. Total coal consumption and ash production for fifteen days

Table 8 and Figure 3 shows the 15 days report of power generation, coal consumption, fly ash production, bottom ash production and net ash production.

Table 8. Coal consumption, fly ash and bottom production and net power generation for fifteen days

\begin{tabular}{|c|c|c|c|c|c|c|}
\hline S. No & Day & $\begin{array}{l}\text { Generation } \\
\text { (MWh) }\end{array}$ & $\begin{array}{l}\text { Coal Consumption } \\
\text { (in tons) }\end{array}$ & $\begin{array}{l}\text { Fly Ash } \\
\text { production } \\
\text { (in tons) }\end{array}$ & $\begin{array}{l}\text { Bottom Ash production } \\
\quad \text { (in tons) }\end{array}$ & $\begin{array}{l}\text { Net Ash production } \\
\text { (in tons) }\end{array}$ \\
\hline 1 & Day 1 & 13537.6 & 11950.41 & 826.44 & 499.88 & 1326.32 \\
\hline 2 & Day 2 & 14523 & 11449.01 & 1005.68 & 480.58 & 1486.26 \\
\hline 3 & Day 3 & 13275.8 & 11465.13 & 943.62 & 460.88 & 1404.5 \\
\hline 4 & Day 4 & 12131.9 & 10485.1 & 956.66 & 407.98 & 1364.64 \\
\hline 5 & Day 5 & 11346.4 & 8886.005 & 958.8 & 357.84 & 1316.64 \\
\hline 6 & Day 6 & 11751.6 & 9829.315 & 924.88 & 288.1 & 1212.98 \\
\hline 7 & Day 7 & 11704.3 & 9844.02 & 876.72 & 429.96 & 1306.68 \\
\hline 8 & Day 8 & 11715.2 & 10827.8 & 906.18 & 245.1 & 1151.28 \\
\hline 9 & Day 9 & 12961 & 10742.41 & 1039.06 & 409.34 & 1448.4 \\
\hline 10 & Day 10 & 13260.1 & 10974 & 1137.12 & 362.48 & 1499.6 \\
\hline 11 & Day 11 & 13160.8 & 11032.45 & 1048.26 & 313.14 & 1361.4 \\
\hline 12 & Day 12 & 13159.4 & 10670.5 & 1058.94 & 259.16 & 1318.1 \\
\hline 13 & Day 13 & 13742 & 11211.33 & 1112.34 & 318.76 & 1431.1 \\
\hline 14 & Day 14 & 14595.4 & 11688.488 & 991.96 & 502.26 & 1494.22 \\
\hline 15 & Day 15 & 14594.6 & 12246.428 & 1027.62 & 447.78 & 1475.4 \\
\hline \multicolumn{2}{|c|}{ Total Production } & 195459.1 & 163302.396 & 14814.28 & 5783.24 & 20597.52 \\
\hline
\end{tabular}




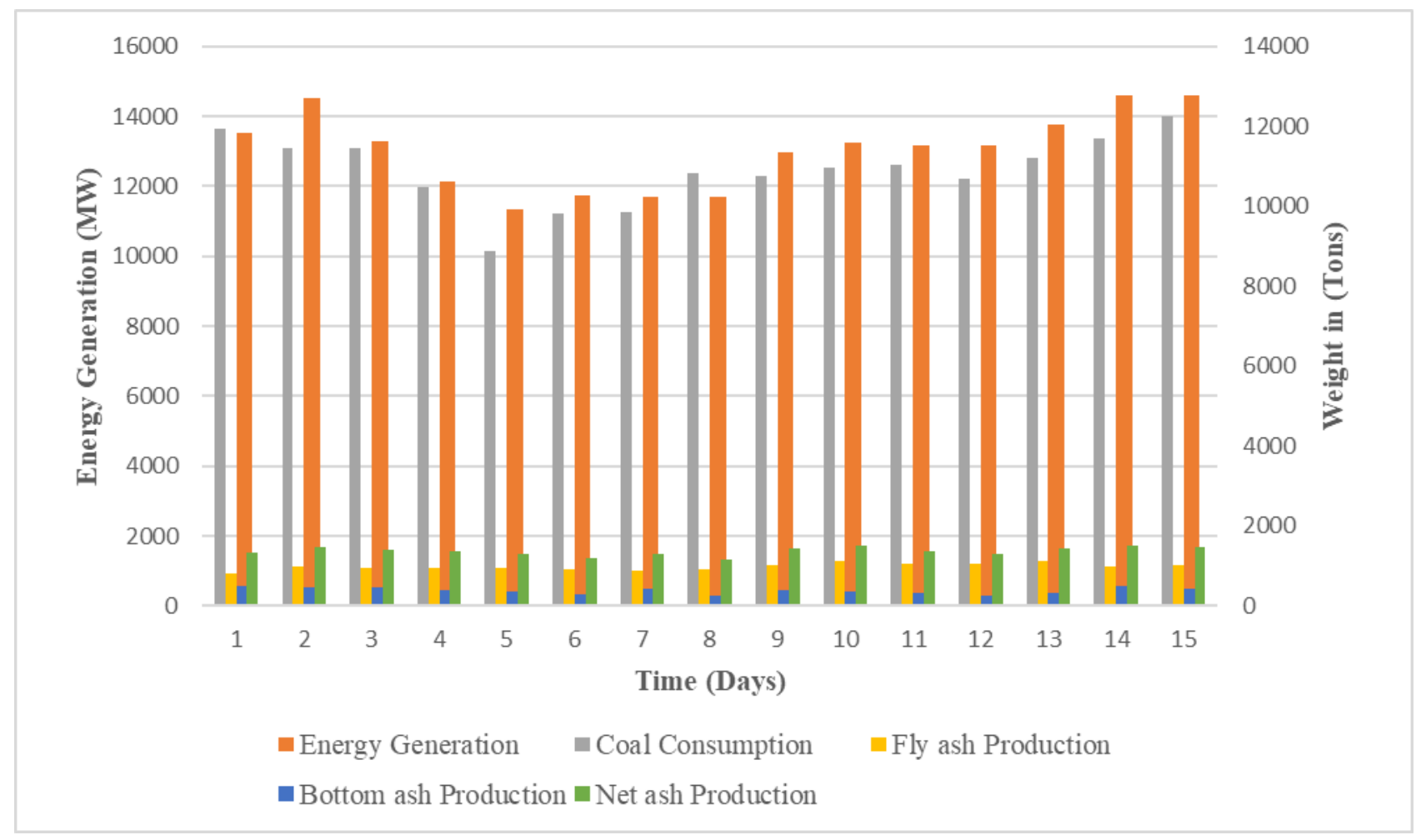

Fig.3. Total coal consumption, ash production (in tons) and net power generation (in MW) chart for fifteen days

\section{Impacts of Ash on Environment}

The particle size of fly ash is ranging from 0.5 to 300 micron in diameter, being light weight, have potential to get airborne easily and pollute the environment [13]. If it is not managed properly than it can causes serious health concern for human and wild life in long time. Additionally, ash contaminates the under-ground water and fresh water resources with traces of toxic metals present in fly ash. In addition, it requires large part of land to dispose or landfill. Indirectly ash also contributes to climate change and global warming. As coal power plants emits lots of greenhouse gases in environment with huge proportion of carbon di oxide.

\section{Utilization of Ash}

Fly Ash is being economically utilized in building structures for example, bricks, roads, stabilization of embankments etc. It is additionally utilized as raw material in agricultural and wasteland development programs. Through research development and application of recycling, fly ash has shifted from "Waste Material" category to "Resource Material" category. Some of the innovative and commonly manufactured ecofriendly building material utilizing fly ash is covered below.

\section{A. Cellular Light Weight Concrete (CLC) Blocks}

CLC blocks can substitute to conventional bricks and concrete blocks in building with density varying from 400 $\mathrm{kg} / \mathrm{m}^{3}$ to $1800 \mathrm{~kg} / \mathrm{m}^{3}$ [11]. Further foamed concrete is manufactured by mixing Portland cement, sand, fly ash, water and preformed foam in varied proportions. CLC blocks have more performance benefits than conventional bricks like lightweight, fire resistance, thermal insulation, sound absorption and acoustical insulation. These blocks are cost-efficient as well.

\section{B. Fly Ash based new Bio-Composites Material as Wood Substitute}

The fly ash-based composites have been developed with Human Hair and composite plates. These composite plates were developing by using CY-230 resin. These bio composite material have good mechanical performance, low-cost, high toughness, and bio-durability. Fly ash based composite has been successfully used for many decades for all engineering applications.

\section{Usage offly ash in cement}

Fly ash possesses pozzolonic properties and it can be used as binding material. For many years fly ash is used as secondry cementitious material along with Portland cement. American Society of Testing Materials categorizes fly ash into 
different types based on $\mathrm{CaO}$ content. Standards allow maximum 30\% replacement of fly ash as partial replacement of cement in concrete which gives adequate performance of concrete. However, according to J. Alam and M.N Akhtar [11], up to $35 \%$ of suitable fly ash can directly be substituted for cement as blending material [11]. Fly ash improves the quality and durability characteristics of concrete and contributes to lower amount of cement usage which results in economical concrete.

\section{Fly Ash in Road Construction}

Fly ash utilization as construction material for enhancing the engineering properties of soil reduces the demand of disposal and hence controls the source of pollution and protects the environment.

\section{E. Use of fly ash in Agriculture}

Element of fly ash like Magnesium, Sulphur, Phosphorus, Potassium improve soil's fertility, physical and chemical properties which results in an increase of crop yields. Further, it improves the water holding capacity of soil and crop grown on fly ash amended soil are safe for human use.

\section{Conclusions}

The aim of this research was to know the quality of Thar Coal fly ash, its production and possible usage. From experimental data it was observed that the Thar coal type is lignite and ash produced is Type $\mathrm{C}$. The coal consumption for energy produces $12 \%$ fly ash which is dumped nearby power plant. The ash disposal can pose serious environmental impact and health hazards if not handled properly.

Possible ways to use fly ash as potential abundant material has also discussed to highlight the recycling of this byproduct. As this study is only based on single power plant but there are twelve more plants which are not in operational condition at this point. However, in future they will be functional to produce energy and fly ash as well. Thus, there is huge availability of fly ash to recycle for different purposes.

For research and development, this ash needs further experimental investigation in different industries like construction. The investigation may include suitability of the ash as secondary cementitious material in concrete, making bricks by replacing ordinary clay in different proportions etc. These researches will open many possibilities to recycle this byproduct efficiently, economically and environmental friendly.

\section{References}

[1] Pakistan Coal Power Generation Potential, Private power and infrastructure board, June 2004.

[2] Pakistan's Thar Coal Power Generation Potential, Private power and infrastructure board, July 2008.

[3] S. Rao, A. R. Sahito, Iqra Panhwar, "Environmental impacts of thar coal mining," in 4th International Conference on Energy, Environment and Sustainable Development, Jamshoro, 2016.

[4] Adven Masih 2018 J. Phys.: Conf. Ser. 989012004.

[5] F. Khan et al, "Financial impediments in harnessing thar coal for the creation of electrical energy in Pakistan," International Journal of Management Sciences, vol. 3, no. 5, pp. 370-378, 2014.

[6] M. R. Senapati, "Fly ash from thermal power plants - waste management and overview," Current Science, vol. 100, no. 12, pp. 1791-1794, June 2011.

[7] R. Chopra, K. Agarwal, and B. Bhardwaj, "Effects of thermal power plants on environment," International Journal of Advance research in Science and Engineering, vol. 6, no. 9, pp. 187-190. September 2017.

[8] W. K. Pokale, "Effects of thermal power plant on environment," Science Reviews and. Chemical Communication, vol. 2. no. 3, pp. 212-215, 2012.

[9] I. Nawaz, "Disposal and utilization of fly ash to protect the environment ," International Journal of Innovative Research in Science, Engineering and Technology, vol. 2, no. 10, pp. 5259-5266, October 2013.

[10] S. Abbas, M. A. Saleem, Syed M.S. Kazmi, and M. J. Munir, "Production of sustainable clay bricks using waste fly ash: mechanical and durability properties," Journal of Building Engineering, Available: http://dx.doi.org/10.1016/j.jobe.2017.09.008.

[11] J.Alam and M.N Akhtar, "Fly ash utilization in different sectors in Indian scenario," International journal of emerging trends in Engineering and Development, vol. 1, no. 1, pp. 1-14, August 2011.

[12] Verma et al.," Heavy metal contamination of groundwater due to fly ash disposal of coal-fired thermal power plant, Parichha, Jhansi, India," Cogent Engineering , Available: http://dx.doi.org/10.1080/23311916.2016.1179243.

[13] S. Kumar, D. Katoria and D. Sehgal, "Environment impact assessment of thermal power plant for sustainable development," International Journal of Environmental Engineering and Management, vol. 4, no. 6, pp. 567-572, 2013.

[14] A. Shamshad, Fulekar M.H., and P. Bhawana, "Impact of coal based thermal power plant on environment and its mitigation measure," International Research Journal of Environment Sciences, vol. 1, no. 4, pp. 60-64, November 2012.

[15] A. Dennis Lemly, "Environmental hazard assessment of coal ash disposal at the proposed rampal power plant," Human and Ecological Risk Assessment: An International Journal, Available: https://doi.org/10.1080/10807039.2017.1395685.

[16] R. K. Singh , N. C. Gupta and B. K. Guha (2012) The Leaching Characteristics of Trace Elements in Coal Fly Ash and an Ash Disposal System of Thermal Power Plants, Energy Sources, Part A: Recovery, Utilization, and Environmental Effects, 34:7, 602-608, DOI: 10.1080/15567036.2011.621928. 
[17] Anila Sarwar, M. N. Khan2, K. F. Azha, "Coal chemistry and morphology of Thar reserves, Pakistan," Journal of Minerals and Materials Characterization and Engineering, pp. 817-824, 2012, Available: http://www.SciRP.org/journal/jmmce.

[18] J. B. Faheem, "Energy Crisis in Pakistan," IRA-International Journal of Technology \& Engineering, vol. 3, no. 1, pp. 1-16, April 2016.

[19] B. K. Patel, V. K Verma, A. K. Rai and A. Gaikwad, "development of fly ash based new bio-composites material as wood substitute." International Journal of Mechanical and Production Engineering Research and Development, vol. 7, no. 3, pp. 1-6, June 2017.

[20] R. P Hardaha, M. L. Agrawal, and A. Agrawal, "Fly ash utilization in road construction with expansive soil,' International Journal of Civil Engineering and Technology, vol. 8. No. 6, pp. 559-566, June 2017.

[21] A. K. Gupta et al, "Fly ash for agriculture: implications for soil properties, nutrients, heavy metals, plant growth and pest control," Agroecology and Strategies for Climate Change, Sustainable Agriculture Reviews 8, DOI 10.1007/978-94-007-19057_11.

[22] Odji Ebenezer, "Aesthetics Application in Solid Waste Management as a Means of Optimising Environmental Sustainability in Urbanizing Third-World Environments", International Journal of Engineering and Manufacturing(IJEM), Vol.9, No.4, pp.1532, 2019. DOI:10.5815/ijem.2019.04.02.

[23] Technical Improvement of Air Pollution Through Fossil Power Plant Waste Management ", International Journal of Engineering and Manufacturing(IJEM), Vol.10, No.4, pp.43-53, 2020. DOI: 10.5815/ijem.2020.04.04.

[24] K Srinivasa Rao, G. Lavanya Devi, N. Ramesh, "Air Quality Prediction in Visakhapatnam with LSTM based Recurrent Neural Networks", International Journal of Intelligent Systems and Applications(IJISA), Vol.11, No.2, pp.18-24, 2019. DOI: 10.5815/ijisa.2019.02.03.

\section{Authors' Profiles}

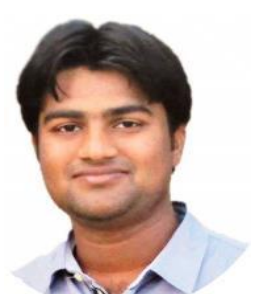

Deepak Kumar is electronics engineer and work as assistant manager in Jamshoro power company limited. The author has research interest in utilization of waste ash in the different useful products. He has also interest to do research in the field of instrumentation and control.

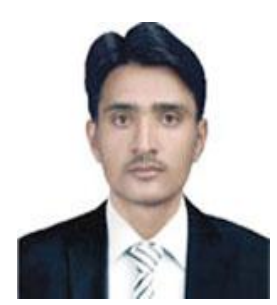

Bharat Lal is Lecturer at Electronic Engineering department at Mehran University of Engineering and Technology, Pakistan. Author has research interest in smart cities, Automation and control, Recycling of waste material, Machine Learning, Artificial Intelligence and Embedded Systems

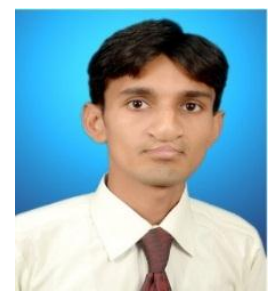

Mukesh Kumar is chemical engineer and work as assistant manager in a power generation company. He has research interest in recycling and reuse of waste material coming from burning of coal. Also has research interest in the field of water treatment technologies to increase the efficiency and reduce the waste production.

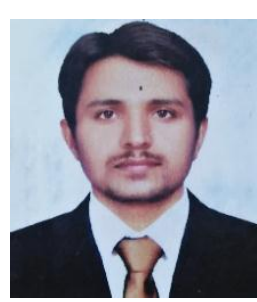

Shanker Lal Meghwar is Lecturer at Civil Engineering in Mehran UET Jamshoro. The author has research interest in secondary cementitious materials, recycling of waste as potential material for concrete and numerical analysis to mimic the behaviour of structural concrete. 
How to cite this paper: Deepak Kumar, Bharat Lal, Mukesh Kumar, Shanker Lal Meghwar, " Quality Analysis of Ash from Lignite Coal and its Utilization at Thar Power Plant ", International Journal of Engineering and Manufacturing (IJEM), Vol.11, No.3, pp. 1827, 2021. DOI: $10.5815 /$ ijem.2021.03.02 